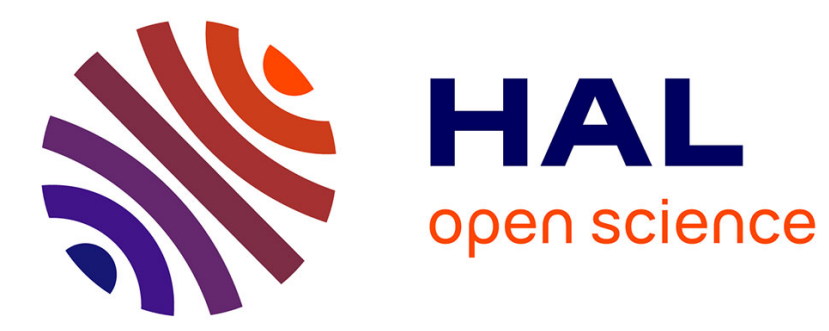

\title{
Visual light photoswitches derived from bindone: Toward stabilization of colored photo-isomers
}

\author{
Vladimir Lokshin, Laura Bekere, Vladimir Khodorkovsky
}

\section{To cite this version:}

Vladimir Lokshin, Laura Bekere, Vladimir Khodorkovsky. Visual light photoswitches derived from bindone: Toward stabilization of colored photo-isomers. Dyes and Pigments, 2017, 145, pp.570-575. 10.1016/j.dyepig.2017.06.052 . hal-03500754

\section{HAL Id: hal-03500754 https://hal.science/hal-03500754}

Submitted on 6 Jan 2022

HAL is a multi-disciplinary open access archive for the deposit and dissemination of scientific research documents, whether they are published or not. The documents may come from teaching and research institutions in France or abroad, or from public or private research centers.
L'archive ouverte pluridisciplinaire HAL, est destinée au dépôt et à la diffusion de documents scientifiques de niveau recherche, publiés ou non, émanant des établissements d'enseignement et de recherche français ou étrangers, des laboratoires publics ou privés.

\section{(1) (1) $\$$}

Distributed under a Creative Commons Attribution - NonCommercial - NoDerivatives| 4.0 


\section{Visual light photoswitches derived from bindone: toward} stabilization of colored photo-isomers.

$$
\text { Vladimir Lokshin, Laura Bekere, Vladimir Khodorkovsky* }
$$

Aix Marseille Université, CNRS, CINaM UMR 7325, 13288, Marseille, France

E-mail: khodor@cinam.univ-mrs.fr

Abstract: Condensation of bindone and cinnamaldehydes afforded five cyclic products instead of the expected merocyanines. The structures of all products were confirmed by the X-ray data. In solution, the weakly colored cyclic isomers form deeply colored (orange to red shades) open isomers upon irradiation in the UV and visible range (up to $530 \mathrm{~nm}$ ). The colored isomers are very stable and undergo thermal discoloration with the half-life times between $13 \mathrm{~h}$ and $128 \mathrm{~h}$, depending on the substituent and solvent at room temperature. Heating their solutions above $130^{\circ} \mathrm{C}$ gives rise to rapid discoloration. High fatigue resistance was demonstrated by repeating the irradiation/heating cycles.

Keywords: Photochromism, Merocyanine, Photochemical switching, bindone.

\section{Introduction}

During the past decades, photochromic derivatives have been the focus of numerous research studies owing to the importance of this class of organic compounds in different fields of materials science [1-3]. 
1 of a chemical species induced in one or both directions by absorption of

2 electromagnetic radiation between two forms, $A$ and $B$, having different

3 absorption spectra and, correspondingly, a difference of other physical

4 properties [4]. Many classes of organic photochromic molecules are therefore

5 considered as molecular switches, namely, photoswitches [5].

Most of the known photochromic molecules undergo photochemical conversions upon action of light of the UV range. However, UV light may damage the polymeric substrates involving photochromic molecules or moieties and its use as a photo-activator for biological and medical applications is very limited. Therefore, the search for molecular photoswitches that can be activated by visible or near infrared light became the focus of numerous researches during the past years [6].

Among the most studied new classes of visible light photoswitches are $o$ fluoroazabenzenes [7, 8] and Donor-Acceptor Stenhouse Adducts (DASA) [9] that exhibit negative photochromism: irradiation of their deeply colored solutions by visible light gives rise to the formation of the colorless cyclic forms. Discoloration is reversible and the color is restored in dark thermally [10-13].

Recently, we described a new photochromic system that exhibits unprecedented behavior: the condensation products of bindone and $p$ aminophenyl substituted cinnamaldehydes or $p$-methoxy cinnamaldehyde produced not the expected colored merocyanines, but weakly colored cyclic derivatives 1a-c [14]. The amino-substituted derivatives 1a,b exhibit two very broad overlapping weak absorption bands between 300 and $650 \mathrm{~nm}\left(\varepsilon<800 \mathrm{M}^{-1}\right.$ 
$1 \mathrm{~cm}^{-1}$ ), whereas the spectra of methoxy substituted 1c shows only one broad band

2 about $480 \mathrm{~nm}$. The yellowish solutions of $\mathbf{1}$ undergo intense coloration upon

3 irradiation by visible light at any wavelength up to $640 \mathrm{~nm}$ (Scheme 1) owing to

4 the formation of the conjugated merocyanines 2 . The process is reversible and

5 the dark discoloration occurs, depending on the temperature and solvent

6 polarity, within seconds and a few hours. Quantum mechanical calculations

7 showed that the presence of a strong electron donating substituent is

8 substantial, as the longest wavelength absorption band of $\mathbf{1}$ is the intramolecular

9 charge transfer band from the $p$-aminophenyl electron donating moiety toward

10 the 1,3-indandione accepting moiety.
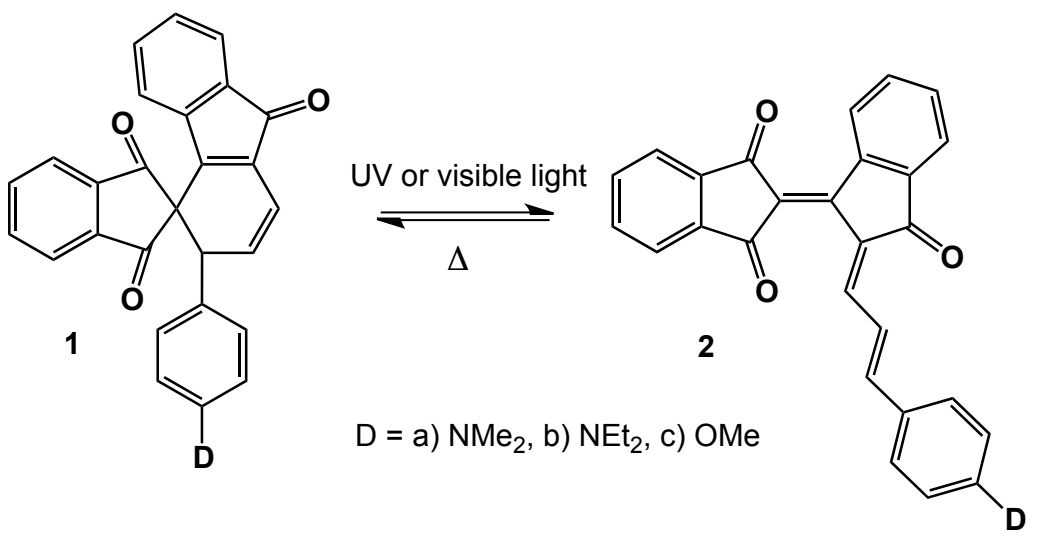

11

12 Scheme 1. Bindone derived photochromes reactive to UV and visible ranges [14].

In this paper we report on the synthesis, structures and photochromic

14 properties of a series of analogs of $\mathbf{2}$ without the electron donating substituents.

15 2. Experimental 
Bindone, cinnamic aldehyde derivatives and solvents were obtained from

2 Sigma- Aldrich and Alfa-Aeser.

${ }^{1} \mathrm{H}$ and ${ }^{13} \mathrm{C}$ NMR spectra were recorded in methylene chloride- $\mathrm{d}_{2}$ on JEOL

$4 \quad$ ECS400 spectrometer at 399.78 and $100.53 \mathrm{MHz}$, respectively. Proton chemical

5 shifts are given in ppm downfield from tetramethylsilane and coupling constants

$6(J)$ in Hertz. ${ }^{13} \mathrm{C}$ NMR spectrum of solid $\mathbf{4 b}$ was recorded on Bruker BioSpin

7 spectrometer at $10 \mathrm{kHz}$. IR spectra were recorded for solid samples on Perkin

8 Elmer Spectrum 100 spectrometer.

Melting points were determined on a Büchi-510 apparatus and were not 10 corrected.

11 The UV-Vis absorption spectra were recorded with Ocean Optics USB 124000 and JASCO V-660 in 2, 4, 10 and $100 \mathrm{~mm}$ quartz cells. Irradiation of 13 solutions was done using a UVP LLC 95000505 lamp (254 nm), LED sources 14 LUMOS 43 (Atlas Photonics) at 300, 315, 330, 350, 405, 450, 505 and $525 \mathrm{~nm}$, 15 Luminus LED PT121 at 460 and $530 \mathrm{~nm}$ and lasers: Module Oxxius LBX-40516 500-HPE-PP 405 nm, LBX-642-130-CIR-PP 642 nm, CryLas FQSS 266-200 (266 17 and $532 \mathrm{~nm}$ ) and FQSS 355-300 (355 $\mathrm{nm})$.

A general procedure: a mixture of bindone 1 (1 $\mathrm{mmol})$ and the 20 corresponding cinnamaldehyde (1.2 mmol) was refluxed in absolute ethanol for 212 - 3 hours. The precipitated in $70-80 \%$ yields products 5 (4b in the case of $p$ 22 fluorophenyl cinnamaldehyde) were washed with ethanol, dried on air and 23 crystallized. 
2.2.1. 3-Phenylspiro[fluorene-4,2'-indene]-1',3',9(3 H)-trione (5a).

Yield: 78\%. Bright scarlet plates from acetic acid, m.p. $230-232^{\circ} \mathrm{C}$ (dec). IR: 1740, 1707 sh, 1699, 1600 sh, $1590 \mathrm{~cm}^{-1} .{ }^{1} \mathrm{H}$ NMR: $7.92(\mathrm{~d}, J=7.6,1 \mathrm{H}), 7.75$ $(\mathrm{td}, J=7.5,1.2,1 \mathrm{H}), 7.69(\mathrm{td}, J=7.5,1.1,1 \mathrm{H}), 7.62(\mathrm{~d}, J=7.6,1 \mathrm{H}), 7.38(\mathrm{~d}, J=7.6$, 1H), $7.12(\mathrm{t}, J=7.1,1 \mathrm{H}), 7.06-6.95(\mathrm{~m}, 6 \mathrm{H}), 6.56(\mathrm{dd}, J=9.7,3.4,1 \mathrm{H}), 6.17(\mathrm{~d}, J=$ 7.3, 1H), $6.07(\mathrm{dd}, J=9.6,2.8,1 \mathrm{H}), 4.71(\mathrm{t}, J=3.1,1 \mathrm{H}) .{ }^{13} \mathrm{C}$ NMR: $202.10(\mathrm{CO})$, 196.36 (CO), 193.13 (CO), 149.09, 142.65, 141.63, 141.52, 137.29, 136.53 (CH), $136.02(\mathrm{CH}), 133.98,133.48(\mathrm{CH}), 131.58,131.38(\mathrm{CH}), 129.42(2 \mathrm{CH}), 129.07$ $(\mathrm{CH}), 128.36(2 \mathrm{CH}), 127.69,123.49,122.87(2 \mathrm{CH}), 120.61(\mathrm{CH}), 117.51(\mathrm{CH})$, 62.11, 50.41 (CH). Anal. calcd. for $\mathrm{C}_{27} \mathrm{H}_{16} \mathrm{O}_{3}$ : C, 83.49\%; H, 4.15\%. Found: C, $83.38 \%, \mathrm{H}, 4.12 \%$.

\subsubsection{3-(4-Fluorophenyl)spiro[fluorene-4,2'-indene]-1',3',9(3 H)-trione (5b).}

Derivative 4b (20 mg, $49 \mathrm{mmol}$ ) was heated under reflux for one hour in $10 \mathbf{m l}$ of octane. Insoluble $\mathbf{4 b}$ slowly dissolves and the resulting orange solution was evaporated and the residue crystallized from acetic acid affording $\mathbf{5 b}$ in $80 \%$ yield. Red prisms m.p. $236-238^{\circ} \mathrm{C}$. IR: $1739,1714,1698,1601,1591 \mathrm{~cm}^{-1} .{ }^{1} \mathrm{H}$ NMR: $7.94(\mathrm{~d}, J=7.5,1 \mathrm{H}), 7.79(\mathrm{t}, J=7.4,1 \mathrm{H}), 7.73(\mathrm{t}, J=7.4,1 \mathrm{H}), 7.66(\mathrm{~d}, J=7.5$ $\mathrm{Hz}, 1 \mathrm{H}), 7.38(\mathrm{~d}, J=7.1,1 \mathrm{H}), 7.10(\mathrm{t}, J=7.4,1 \mathrm{H}), 7.04-6.98(\mathrm{~m}, 3 \mathrm{H}), 6.72(\mathrm{t}, J=8.7$, $2 \mathrm{H}), 6.56(\mathrm{dd}, J=9.7,3.4,2 \mathrm{H}), 6.17(\mathrm{~d}, J=7.3,2 \mathrm{H}), 6.03(\mathrm{dd}, J=9.7,2.9,2 \mathrm{H}), 4.72$ (t, $J=3.1,2 \mathrm{H}) .{ }^{13} \mathrm{C}$ NMR: 202.05 (CO), 196.35 (CO), 193.04 (CO), 162.08 (d, $J=$ 246.4, CF), 149.04, 142.57, 141.53, 141.42, $136.76(\mathrm{CH}), 136.26(\mathrm{CH}), 133.87$ $133.51(\mathrm{CH}), 133.24\left(\mathrm{~d},{ }^{4} \mathrm{~J}=3.2\right), 131.54,131.11\left(\mathrm{~d},{ }^{2} \mathrm{~J}=12.2,2 \mathrm{CH}\right), 131.09(\mathrm{CH})$, $129.14(\mathrm{CH}), 123.59(\mathrm{CH}), 122.94\left(\mathrm{~d},{ }^{3} \mathrm{~J}=3.8,2 \mathrm{CH}\right), 120.63(\mathrm{CH}), 117.67(\mathrm{CH})$, 
$1115.31(\mathrm{CH}), 115.10(\mathrm{CH}), 62.03,49.51(\mathrm{CH})$. Anal. calcd. for $\mathrm{C}_{27} \mathrm{H}_{15} \mathrm{FO}_{3}$ : C,

2 79.79\%; H, 3.72\%. Found: C, 79.92\%, H, 3.91\%.

3

4 2.2.3. (2Z)-2-[(2E)-3-(4-Fluorophenyl)prop-2-en-1-ylidene]-1,2'-biindene-1',3,3'(2 H)- trione (4b).

6

7

Yield: 79\%. Brown needles with metallic luster, m.p. 220-221ํㄷ. IR: 1696, 1672, 1607, 1587, 1565, 1530, $1509 \mathrm{~cm}^{-1} .{ }^{1} \mathrm{H}$ NMR: 9.08(d, $\left.J=7.8,1 \mathrm{H}\right), 8.70$ (dd, $J$ $=15.4,11.8,1 \mathrm{H}), 8.10(\mathrm{~d}, J=11.7,1 \mathrm{H}) .{ }^{13} \mathrm{C}$ NMR (solid): 190.18, 187.82, 167.13, $163.84,155.42,151.96,147.17,140.16,137.71,133.61,130.93,127.04,124.50$, 121.97, 119.54, 117.32. Anal. calcd. for $\mathrm{C}_{27} \mathrm{H}_{15} \mathrm{FO}_{3}$ : C, 79.79\%; $\mathrm{H}, 3.72 \%$. Found: $\mathrm{C}$, $79.88 \%, \mathrm{H}, 3.76 \%$.

2.2.4. 3-(4-Chlorophenyl)spiro[fluorene-4,2'-indene]-1',3',9(3 H)-trione (5c).

Yield: $77 \%$. Red prisms from ethanol, m.p. $184-185^{\circ} \mathrm{C}$. IR: 1738,1713 , 1701, 1600 sh, $1588 \mathrm{~cm}^{-1} .{ }^{1} \mathrm{H}$ NMR: $7.95(\mathrm{~d}, J=7.5,1 \mathrm{H}), 7.81(\mathrm{t}, J=7.4,1 \mathrm{H}), 7.75$ $(\mathrm{t}, J=7.4,1 \mathrm{H}), 7.67(\mathrm{~d}, J=7.9,1 \mathrm{H}), 7.38(\mathrm{~d}, J=7.1,1 \mathrm{H}), 7.10(\mathrm{t}, J=7.2,1 \mathrm{H}), 7.03-$ $6.95(\mathrm{~m}, 5 \mathrm{H}) 6.56(\mathrm{dd}, J=9.6,3.4,1 \mathrm{H}), 6.16(\mathrm{~d}, J=7.3,1 \mathrm{H}), 6.01(\mathrm{dd}, J=9.7,2.9$, 1H), $4.71(\mathrm{t}, J=3.1,1 \mathrm{H}) .{ }^{13} \mathrm{C}$ NMR: 201.85, 196.23, 192.99, 148.96, 142.51, 141.49, 141.36, $136.86(\mathrm{CH}), 136.38(\mathrm{CH}), 136.02,133.82,133.53(\mathrm{CH}), 133.50$, 131.53, $130.86(2 \mathrm{CH}), 130.74(\mathrm{CH}), 129.16(\mathrm{CH}), 128.51(2 \mathrm{CH}), 123.65(\mathrm{CH})$, $123.02(\mathrm{CH}), 122.94(\mathrm{CH}), 120.65(\mathrm{CH}), 117.78(\mathrm{CH}), 61.90,49.51(\mathrm{CH})$. Anal. calcd. for $\mathrm{C}_{27} \mathrm{H}_{15} \mathrm{ClO}_{3}$ : C, 76.69\%; $\mathrm{H}, 3.58 \%, \mathrm{Cl}, 8.38 \%$. Found: $\mathrm{C}, 76.72 \%, \mathrm{H}$, $3.66 \%, \mathrm{Cl}, 8.24 \%$.

2.2.5. 3-(4-Bromophenyl)spiro[fluorene-4,2'-indene]-1',3',9(3 H)-trione (5d). 
Yield: 72\%. Red crystals from ethanol, m.p. $208-210^{\circ} \mathrm{C}, \mathrm{IR}: 1742,1713$,

2.2.6. 2-Methoxy-4-(1',3',9-trioxo-1',3,3',9-tetrahydrospiro[fluorene-4,2'-inden]-3yl)phenyl acetate (5e).

Yield: $75 \%$. Red prisms from ethanol, m.p. $190-192^{\circ} \mathrm{C}$. IR: 1759,1704 , 1603, 1592, $1513 \mathrm{~cm}^{-1} .{ }^{1} \mathrm{H}$ NMR: $7.94(\mathrm{~d}, J=7.6,1 \mathrm{H}), 7.79(\mathrm{t}, J=7.4,1 \mathrm{H}), 7.74(\mathrm{t}$, $J=7.6,1 \mathrm{H}), 7.66(\mathrm{~d}, J=7.5,1 \mathrm{H}), 7.38(\mathrm{~d}, J=7.0,1 \mathrm{H}), 7.11(\mathrm{t}, J=7.5,1 \mathrm{H}), 7.02(\mathrm{t}, J$ $=7.5,1 \mathrm{H}), 6.65(\mathrm{~d}, J=8.0,1 \mathrm{H}), 6.61-6.55(\mathrm{~m}, 3 \mathrm{H}) 6.19(\mathrm{~d}, J=7.3,1 \mathrm{H}), 6.09(\mathrm{dd}, J$ $=9.7,2.8,1 \mathrm{H}), 4.72(\mathrm{t}, J=3.0,1 \mathrm{H}), 3.64(\mathrm{~s}, 3 \mathrm{H}), 2.12(\mathrm{~s}, 3 \mathrm{H})$.

${ }^{13}$ C NMR: 202.22, 196.44, 193.05, 168.42, 150.87, 149.08, 142.67, 141.57, 141.50, 139.25, $136.81(\mathrm{CH}), 136.19(\mathrm{CH}), 136.14,133.90,133.51(\mathrm{CH}), 131.56,130.95$ (CH), $129.15(\mathrm{CH}), 123.57(\mathrm{CH}), 122.91(\mathrm{CH}), 122.77(\mathrm{CH}), 122.64(\mathrm{CH}), 121.75$ $(\mathrm{CH}), 120.64(\mathrm{CH}), 117.73(\mathrm{CH}), 113.67(\mathrm{CH}), 62.14,55.90(\mathrm{CH}), 50.37(\mathrm{CH})$, $20.30(\mathrm{CH})$. Anal. calcd. for $\mathrm{C}_{30} \mathrm{H}_{20} \mathrm{O}_{6}$ : C, 75.62\%; H, 4.23\%;. Found: C, 75.51\%, H, $4.45 \%$. 
2 2.2.7. (2Z)-2-(3,3-Diphenylprop-2-en-1-ylidene)-1,2'-biindene-1',3,3'(2H)-trione 3 (6).

4 Yield 70\%. Dark violet needles with green luster from octane/toluene, 5 m.p. $240-241^{\circ}$ C. IR: 1687, 1670, 1595, 1583, 1559, $1509 \mathrm{~cm}^{-1} .{ }^{1} \mathrm{H}$ NMR: 9.05 (d, J $6=7.9,1 \mathrm{H}), 8.66(\mathrm{~d}, J=12.3,1 \mathrm{H}), 7.92-7.70(\mathrm{~m}, 7 \mathrm{H}), 7.69(\mathrm{t}, J=6.9,1 \mathrm{H}), 7.63(\mathrm{t}, J$ $7=6.9,1 \mathrm{H}), 7.50-7.32(\mathrm{~m}, 9 \mathrm{H}) .{ }^{13} \mathrm{C}$ NMR: 191.35, 190.27, 188.14, 160.68, 158.63, $8148.23(\mathrm{CH}), 143.38,141.74,141.44,141.00,138.93,134.82(\mathrm{CH}), 134.63(\mathrm{CH})$, $9133.46(\mathrm{CH}), 131.71(2 \mathrm{CH}), 130.39(2 \mathrm{CH}), 130.10(\mathrm{CH}), 129.84,129.50(2 \mathrm{CH})$, $10129.16(\mathrm{CH}), 128.56(2 \mathrm{CH}), 128.00(2 \mathrm{CH}), 126.10,123.55(\mathrm{CH}), 122.94(\mathrm{CH})$, $11122.80(\mathrm{CH}), 122.66(\mathrm{CH})$. Anal. calcd. for $\mathrm{C}_{33} \mathrm{H}_{20} \mathrm{O}_{3}: \mathrm{C}, 85.33 \% ; \mathrm{H}, 4.34 \%$. Found: 12 C, 85.48\%, H, 4.46\%.

\subsection{Crystallographic data}

15

X-ray crystallography data were collected on a Bruker-Nonius KappaCCD

17 diffractometer with CCD detector using MoK $\alpha$ radiation, $\lambda=0.71073 \AA$. The CIF 18 files have been deposited at the Cambridge Crystallographic Data Centre: 5a: 19 CCDC 1551457, 5b: CCDC 1551461, 5c: CCDC 1551459, 5d: CCDC 1551462, 5e: 20 CCDC 1551460, 6: CCDC 1551458.

\section{Results and discussion}

3.1. Synthesis and structures. 
1 available bindone (1,2'-biindene-1',3,3'(2H)-trione, 3$)$ and the respective

2 cinnamic aldehydes (Scheme 2). All derivatives, except $\mathbf{4 b}$, precipitated from the

3 reaction mixture as cyclic isomers 5 according to their ${ }^{1} \mathrm{H}$ and ${ }^{13} \mathrm{C}$ NMR spectra.

4 Derivative 5a has been prepared at the beginning of $20^{\text {th }}$ century, described as 5 merocyanine 4a [15], and since then, to the best of our knowledge, no derivatives

6 of this type had been mentioned in the literature. In the case of $p$-fluorophenyl

7 cinnamaldehyde, the product of the reaction precipitates as poorly soluble thin 8 brownish shining needles. The IR $\left(v_{\mathrm{C}=0}\right.$ at $1696(\mathrm{~s}) 1672(\mathrm{as}) \mathrm{cm}^{-1}$ of the $1,3-$

9 indandione moiety), and ${ }^{13} \mathrm{C}$ NMR spectra $\left(\delta_{\mathrm{C}=0}=190.18,187.82,167.13 \mathrm{ppm}\right)$ of

10 solid samples indicated the structure of $\mathbf{4 b}$. It is stable as the solid but attempts

11 to dissolve it resulted in the relatively slow at room temperature and rapid 12 above $100^{\circ} \mathrm{C}$ conversion into cyclic isomer 5b. Irradiation of a concentrated 13 solution of $\mathbf{5 b}$ in octane afforded precipitation of $\mathbf{4 b}$ as the same thin brownish 14 needles. It is noteworthy that the isolation of both components of a thermo15 reversible photochromic system as pure substances is a very rare case. Condensation of bindone with 3,3-diphenylacrylaldehyde in ethanol 17 afforded merocyanine-type derivative 6. This compound is not photochromic 18 and does not convert into the cyclic form even upon prolonged heating. The X-ray structures were determined for derivatives $\mathbf{5 a}-\mathbf{e}$ and $\mathbf{6}$ (Fig. 20 1). All structures of $\mathbf{5 a}-\mathbf{e}$ involve long $3 \mathrm{C}-4 \mathrm{C}$ bonds $(1.58-1.59 \AA)$ that are 21 somewhat longer than observed previously [14] in the structures of $\mathbf{1 a}-\mathbf{c}(1.57$ $22-1.58 \AA$ ). These bond length variations do not correlate with the substituents 23 nature within the series and can stem from the differences in the C-H...O 24 intermolecular H-bond patterns. At least four short intermolecular C-H...O 
1 distances ranging from 3.91 to $3.62 \AA$ can be found in the crystal lattice of each

2 derivative.
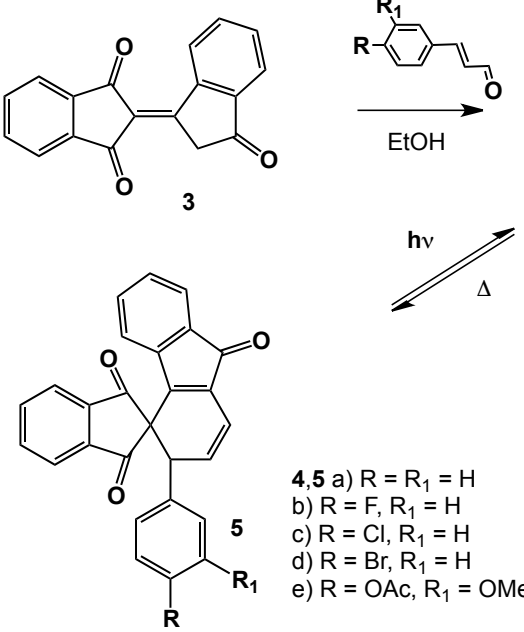

4,5 a) $\mathrm{R}=\mathrm{R}_{1}=\mathrm{H}$

b) $\mathrm{R}=\mathrm{F}, \mathrm{R}_{1}=\mathrm{H}$

c) $\mathrm{R}=\mathrm{Cl}, \mathrm{R}_{1}=\mathrm{H}$

d) $\mathrm{R}=\mathrm{Br}, \mathrm{R}_{1}=\mathrm{H}$

$R=O A c, R_{1}=O M e$

3
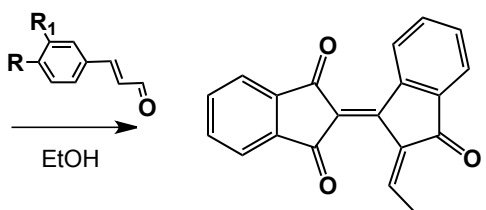

4

$(Z, E)$<smiles>[R]c1ccc(C)cc1[R]</smiles>

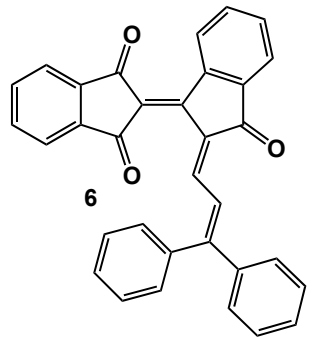

$4 \quad$ Scheme 2. Synthesis and interconversion of derivatives 4 and $\mathbf{5 .}$

5 

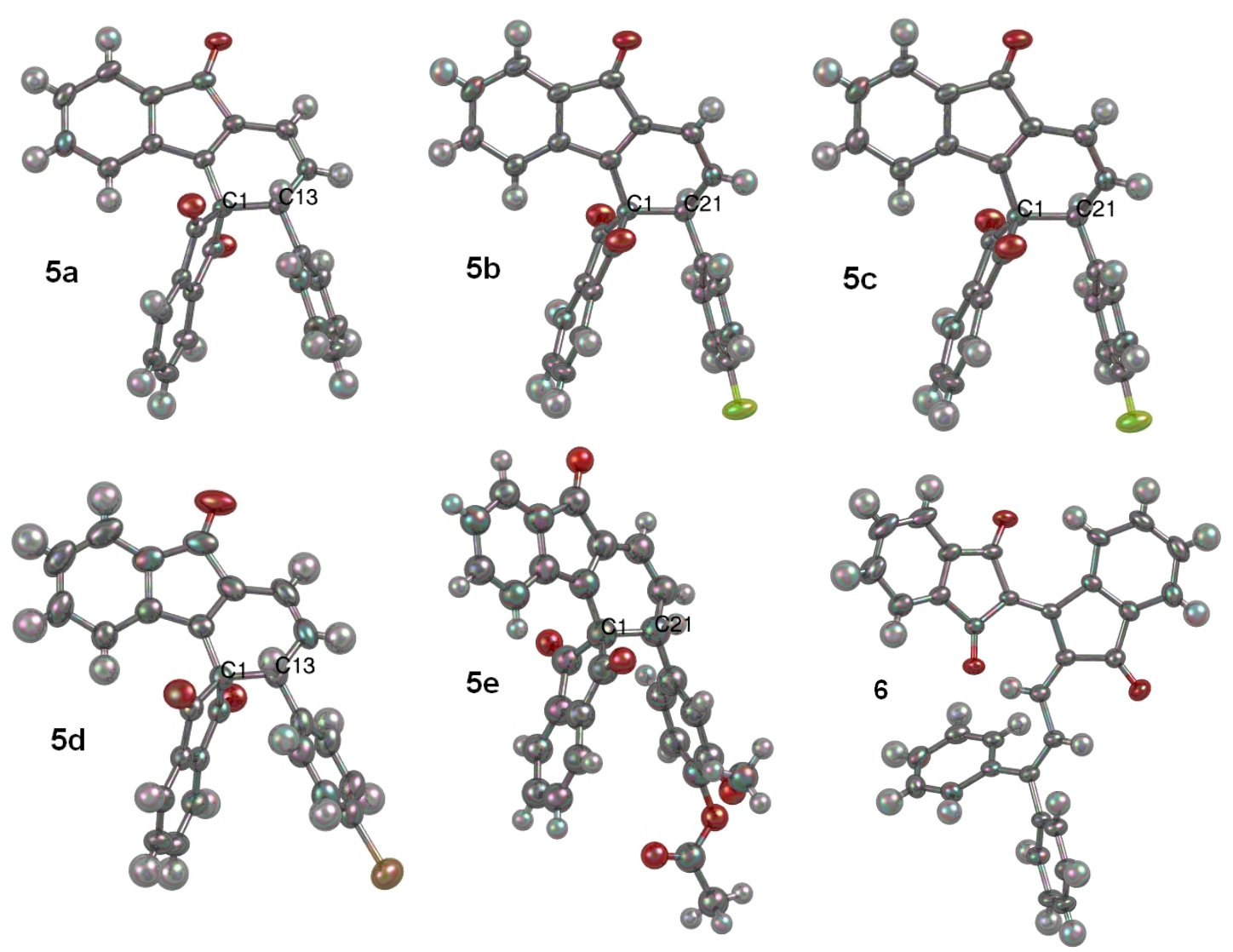

2 Fig. 1. ORTEP diagrams (50\% probability ellipsoids) of $\mathbf{5 a}-\mathbf{e}$ and $\mathbf{6}$. Selected

3 bond length $(\AA)$. 5a, C1-C13: 1.589(2); 5b, C1-C21: 1.585(2); 5c, C1-C21:

$4 \quad$ 1.575(4); 5d, C1-C13: 1.581(3); 5e, C1-C21: 1.577(2).

5

6

Upon irradiation cyclic isomers $\mathbf{5}$ in solution undergo rapid conversion

9 into conjugated open isomers 4. The respective absorption spectra changes are

10 shown in Fig. 2a on the example of $\mathbf{5 a}$ to $\mathbf{4 a}$ isomerization. Two isosbestic points

11 at 252 and $280 \mathrm{~nm}$ are observed. The solutions of 5 are pinkish and on light

12 change the color to deep orange - red (Fig. 2b). Variation of the substituents at 
1 the phenyl group has very little effect on the absorption spectra of derivatives $\mathbf{5 a}$

2 - e, which are practically identical and resemble the spectrum of 1c. Only one

3 broad weak absorption band with the maximum at about $480 \mathrm{~nm}\left(600-800 \mathrm{M}^{-}\right.$

$4{ }^{1} \mathrm{~cm}^{-1}$ ) is observed for isomers $\mathbf{5}$, in contrast to derivatives $\mathbf{2 a}, \mathbf{b}$, which exhibit

5 two low intensity absorption bands centered at about 480 and $600 \mathrm{~nm}$. The

6 absorption spectra the photo-induced open isomers 4 are also very similar (Fig.

7 2b). The spectra of these isomers exhibit four bands with the maxima at about

$8500\left(7200 \mathrm{M}^{-1} \mathrm{~cm}^{-1}\right), 430\left(12000 \mathrm{M}^{-1} \mathrm{~cm}^{-1}\right)$ and $360\left(16000 \mathrm{M}^{-1} \mathrm{~cm}^{-1}\right)$. The

9 structures of $\mathbf{4}$ are corroborated also by the close similarity of their spectra with

10 the spectrum of derivative 6.

11 The ${ }^{1} \mathrm{H}$ NMR spectra for solutions of pure derivatives 4 cannot be

12 recorded owing to thermal conversion into $\mathbf{5}$ during the spectra recording and

13 very low solubility of isolated $\mathbf{4 b}$. Nevertheless, the exceptional stability of

14 isomers 4 allowed to photochemically accumulate them in a sufficient for ${ }^{1} \mathrm{H}$

15 NMR spectra concentrations (up to $50 \%$ conversion of 5 into 4 ). Thus, the signals 16 at $9.08(\mathrm{~d}, J=7.8,1 \mathrm{H}), 8.70(\mathrm{dd}, J=15.4,11.8,1 \mathrm{H})$ and $8.12(\mathrm{~d}, J=11.8,1 \mathrm{H})$, not

17 overlapping with the signals of cyclic isomers $\mathbf{5}$, observed in the spectra of 18 irradiated samples clearly indicate the existence of 4 as $Z, E$-isomers [14]. The 19 similar features exhibit also ${ }^{1} \mathrm{H}$ NMR spectrum of 6. 

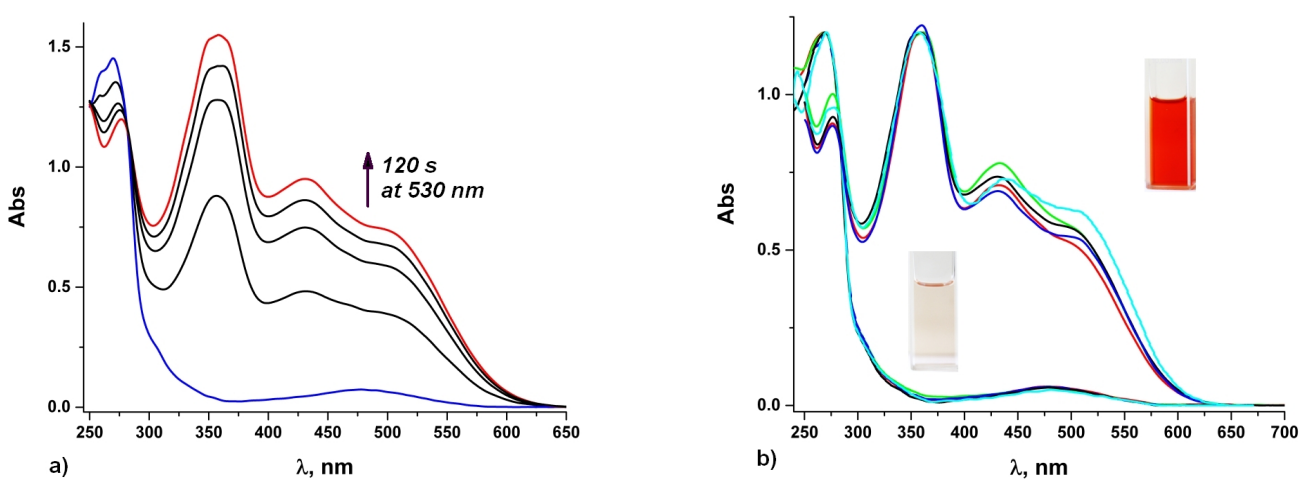

2 Fig. 2. a) Irradiation of $\mathbf{5 a}$ in methylene chloride. b) Absorption spectra of $\mathbf{4}$

3 (generated at $530 \mathrm{~nm}$ ) and $\mathbf{5}$ in methylene chloride: black - a, blue - b, green - c,

4 red - d, cyan - e.

The absorption bands of photogenerated open isomers $\mathbf{4}$ and $\mathbf{6}$ are

6 similar and exhibit slightly positive solvatochromic shifts (Fig. 3).

Thermal discoloration rates of $\mathbf{4}$ follow the first order kinetics, but are

8 considerably slower than those observed previously for derivatives 2. Thus,

9 whereas the half-life time of $\mathbf{2 a}$ in methylene chloride at $25^{\circ} \mathrm{C}$ is $9.3 s$ and of $\mathbf{2 b}-$

$101.44 s$, the half-life times of the open isomers 4 vary between $11.3 h(\mathbf{4 a})$ and

$1117.5 h(4 \mathbf{c}$ and $\mathbf{d})$ in this solvent. Discoloration in non-polar solvents occurs even

12 slower: the half-life time of $\mathbf{4 a}$ in $o$-xylene is $65.0 \mathrm{~h}$ and of $\mathbf{4 c}$ in octane amounts

$13128.4 h$. The half-life time of $\mathbf{2 c}$ in methylene chloride is $2.7 h$. The kinetic data in

14 methylene chloride are summarized in Fig. 4.

The effect of temperature on the rates of thermal discoloration was

16 monitored at 25,50 and $65^{\circ} \mathrm{C}$ and presented in Fig. 5. The activation energies

17 ranging from 24.6 to $26 \mathrm{kcal} / \mathrm{mol}(102.9-109 \mathrm{~kJ} / \mathrm{mol})$ were estimated from the 18 Arrhenius plot. 
The observed first order discoloration kinetics is apparently related to

2 the rate-determining isomerization of the $Z, E$-isomers of 4 (incapable of

3 cyclization) into the $E, E$ and $E, Z$-isomers. The half-life times, indeed, correlate

4 with the electron donating and accepting strength of the substituents at the

5 phenyl ring: the increase in the accepting strength and the decrease of the

6 solvent polarity give rise to the enhanced half-life times of 4 . The activation

7 energies for $\mathbf{2 c}$, $\mathbf{4 a}$ and $\mathbf{4 e}$ are noticeably higher than found for DASA [12] and

8 most of spiroheterocyclic compounds [16].

9

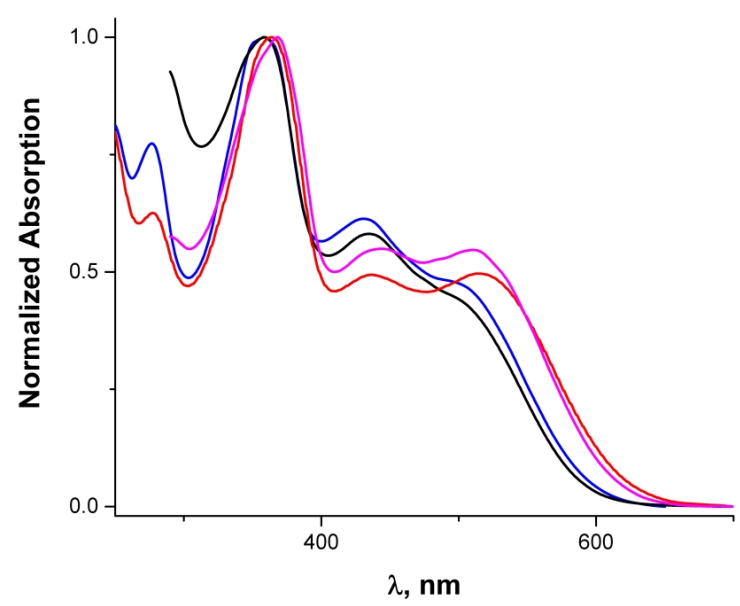

10 Fig. 3. Normalized absorption spectra in toluene $\mathbf{4 a}$ - black, 6 - magenta; in

11 methylene chloride: $\mathbf{4 a}$ - blue, $\mathbf{6}$ - red. 


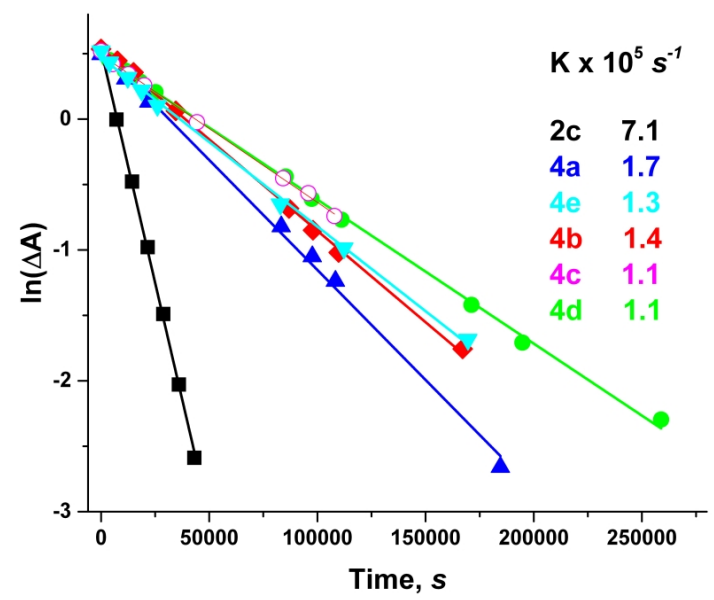

1

2 Fig. 4. Thermal discoloration kinetics of $\mathbf{2 c}, \mathbf{4 a - d}$ in methylene chloride at $25^{\circ} \mathrm{C}$.

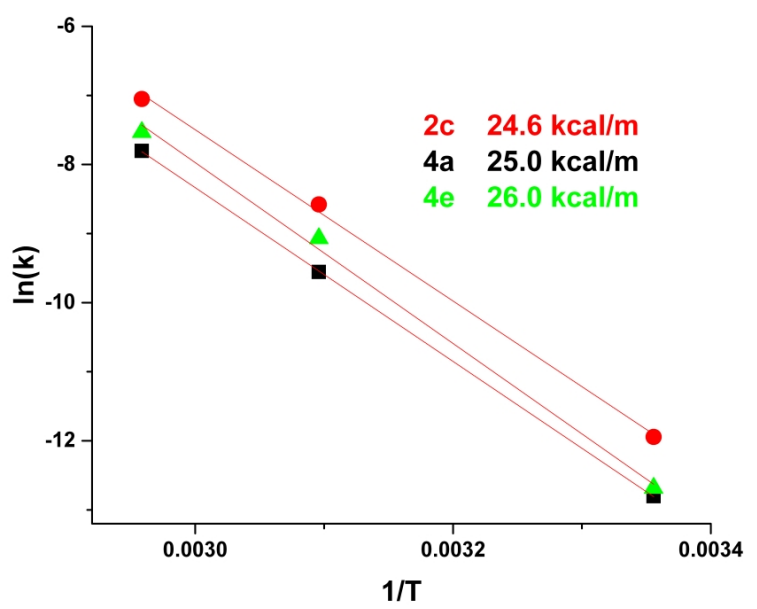

4 Fig. 5. Temperature dependence of rate constants of thermal discoloration in

5 toluene at 25,50 and $65^{\circ} \mathrm{C}$.

6

7

8 The fatigue resistance, as an important characteristic of switching 9 performance, was tested for derivative $\mathbf{5 c}$ in xylene and butylacetate (Fig. 6a, b) 10 by repetition of irradiation at room temperature and heating. 

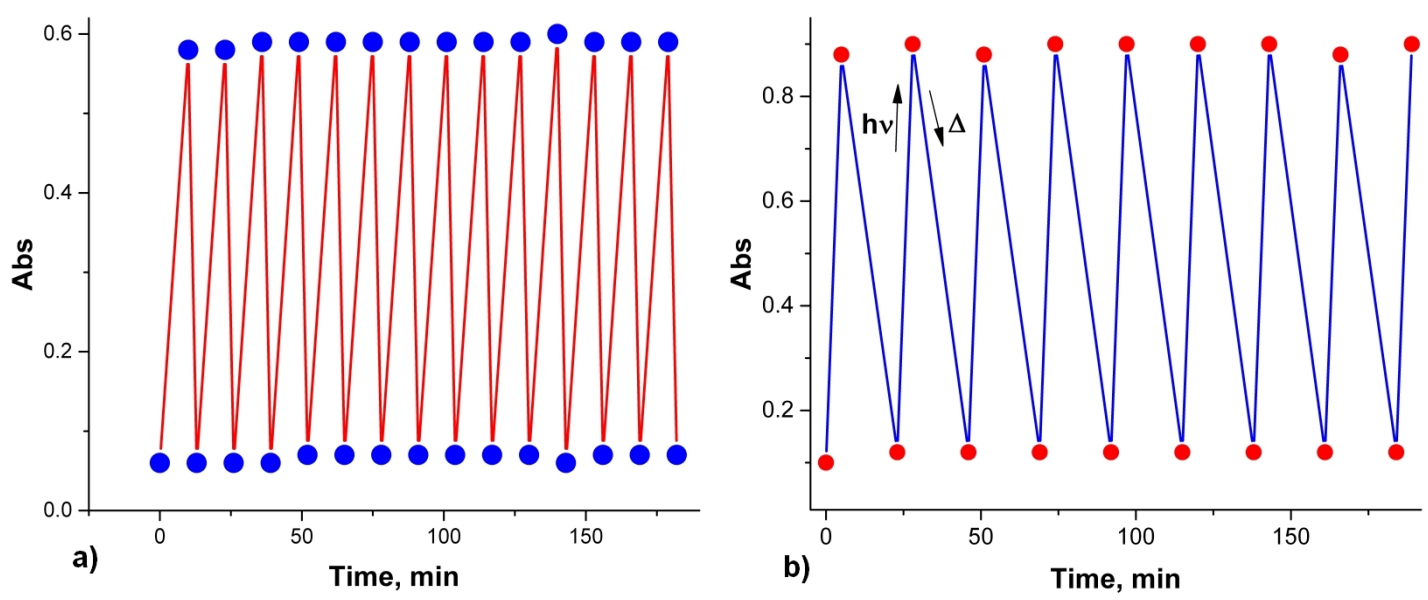

2 Fig. 6. Irradiation of $\mathbf{5 c}$ at $530 \mathrm{~nm}$ and heating cycles: a) in xylene, $10 \mathrm{~min}$

3 irradiation, $3 \mathrm{~min}$ heating at $130^{\circ} \mathrm{C}$; b) in butylacetate, 5 min irradiation, $18 \mathrm{~min}$

4 heating at $100^{\circ} \mathrm{C}$. Absorbance recorded at $500 \mathrm{~nm}$.

5

6

Derivatives 5 exhibit photochromic behavior also in solid polymer

7 matrices. Thus, thin films prepared by spin-coating solutions of $\mathbf{5}$, PMMA or

8 polystyrene in methylene chloride produced well resolved images upon

9 irradiation at $530 \mathrm{~nm}$ (Fig. 7). The images are visible during several days at room

10 temperature and their stability increases at lower temperatures or when the

11 residual solvent is removed in vacuum after irradiation.

12

13

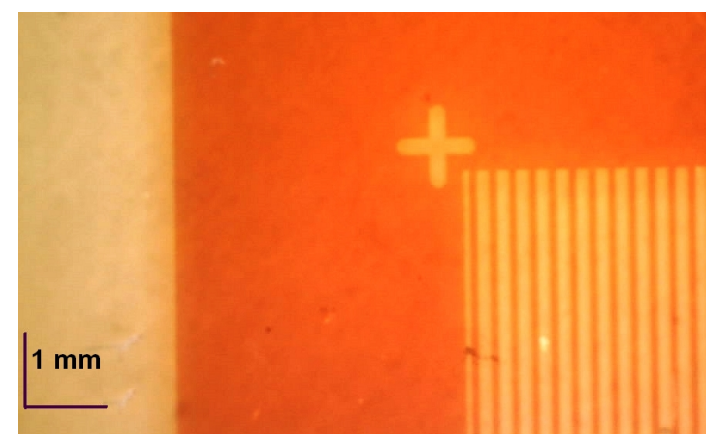

15 Fig. 7. Thin film of 5a in PMMA irradiated at $530 \mathrm{~nm}$ by a DLP projector. 


\section{4. Conclusions}

2

4 reacting with green and red light we prepared derivatives 5 not involving

5 electron donating groups. The new photochromes can easily be prepared from

6 commercially available precursors in one step. In spite of the changes in the

7 electronic structure, evidenced by the respective change in the absorption 8 spectra (the absence of the longest wavelength intramolecular charge transfer

9 band), these derivatives also exhibit photochromic properties. Both UV and 10 visible light up to $530 \mathrm{~nm}$ can activate the reversible color change. The photo11 generated merocyanines $\mathbf{4}$ are considerably more thermally stable than their 12 analogs 2 and their thermal discoloration occurs during several hours or days.

13 The merocyanine isomer $\mathbf{4 b}$ can be isolated and is stable at least for several 14 months in solid state. The photoswitches retain the photochromic properties 15 also in a polymer matrix. However, not all structure variations lead to the 16 photochromic behavior as demonstrated on the example of a stable merocyanine 176. public, commercial, or not-for-profit sectors. 


\section{$1 \quad$ References}

2

3 [1] Crano JC, Guglielmetti RJ. Organic Photochromic and Thermochromic

4 Compounds: Main Photochromic Families (Topics in Applied Chemistry). New

5 York: Plenum Press; 1999.

6 [2] Dürr H, Bouas-Laurent H. Photochromism: Molecules and Systems.

7 Amsterdam: Elsevier Science; 2003.

8 [3] Tian H, Zhang J. Photochromic Materials: Preparation, Properties and

9 Applications. Weinheim: Wiley-VCH; 2016.

10 [4] Bouas-Laurent H, Dürr H. Organic photochromism (IUPAC Technical Report).

11 Pure and Applied Chemistry 2001;73:639-35.

12 [5] Feringa BL. Molecular Switches. Weinheim: Wiley-VCH; 2001.

13 [6] Bléger D, Hecht S. Visible-Light-Activated Molecular Switches. Angew Chem Int $14 \quad$ Ed 2015;54:11338-49.

15 [7] Knie C, Utecht M, Zhao F, Kulla H, Kovalenko S, Brouwer AM, Saalfrank P, 16 Hecht S, Bléger D. Fluoroazobenzenes: Visible Light Switches with Very Long-Lived 17 Isomers. Chem Eur J 2014;20:16492-501.

18 [8] Bléger D, Schwarz J, Brouwer AM, Hecht S. Fluoroazobenzenes as Readily 19 Synthesized Photoswitches Offering Nearly Quantitative Two-Way Isomerization 20 with Visible Light. J Am Chem Soc 2012;134:20597-600.

21 [9] Lewis KG, Mulquiney CE. Aspects of the formation and use of stenhouse salts 22 and related compounds. Tetrahedron 1977;33:463-75.

23 [10] Helmy S, Oh S, Leibfarth FA, Hawker CJ, Read de Alaniz J. Design and 24 Synthesis of Donor-Acceptor Stenhouse Adducts: A Visible Light Photoswitch 25 Derived from Furfural. J Org Chem 2014;79:11316-29. 
1 [11] Helmy S, Leibfarth FA, Oh S, Poelma JE, Hawker CJ, Read de Alaniz J.

2 Photoswitching Using Visible Light: A New Class of Organic Photochromic

3 Molecules. J Am Chem Soc 2014;136:8169-72.

4 [12] Hemmer JR, Poelma SO, Treat N, Page ZA, Dolinski N, Diaz YJ, Tomlinson W,

5 Clark KD, Hooper JP, Hawker CJ, Read de Alaniz J. Tunable Visible and Near

6 Infrared Photoswitches. J Am Chem Soc 2016;138:13960-66.

7 [13] Lerch MM, Wezenberg SJ, Szymanski W, Feringa BL. Unraveling the

8 Photoswitching Mechanism in Donor-Acceptor Stenhouse Adducts. J Am Chem Soc

$9 \quad 2016 ; 138: 6344-47$.

10 [14] Bekere L, Larina N, Lokshin V, Ellern A, Sigalov M, Khodorkovsky V. A new

11 class of spirocyclic photochromes reacting with light of both UV and visible ranges.

12 New J Chem 2016;40:6554-58.

13 [15] Hoyer E. Ueber einige Abkömmlinge des Anhydrobisdiketohydrindens. Ber

14 Dtsch Chem Ges 1901;34:3269-74.

15 [16] Minkin VI. Photo-, thermo-, solvato-, and electrochromic spiroheterocyclic

16 compounds. Chem Rev 2004; 104: 2751-76. 